Bioedusiana

Volume 01, Nomor 01, September 2016

ISSN 2477-5193

\title{
PERBEDAAN HASIL BELAJAR DAN KEMAMPUAN BERPIKIR KRITIS MAHASISWA PENDIDIKAN BIOLOGI MENGGUNAKAN PENDEKATAN PEMBELAJARAN DEDUKTIF DAN INDUKTIF PADA KONSEP EKOSISTEM
}

\author{
Liah Badriah 1) \\ Jurusan Pedidikan Biologi, FKIP, Universitas Siliwangi \\ Jl. Siliwangi Tasikmalaya.
}

\begin{abstract}
ABSTRAK : Penelitian ini bertujuan untuk mengetahui perbedaan hasil belajar dan kemampuan berpikir kritis mahasiswa biologi yang proses pembelajarannya menggunakan pendekatan deduktif dan induktif pada konsep ekosistem. Metode penelitian ini adalah komparatif yang menggunakan rancangan posttest control group design dengan populasi seluruh mahasiswa Semester II Program Studi Pendidikan Biologi FKIP UNSIL dengan sampel 2 kelas sebanyak 67 orang. Pengumpulan data dilakukan dengan posttest untuk memperoleh data kemampuan akhir hasil belajar dan rubrik untu $\quad k$ kemampuan berpikir kritis mahasiswa, teknik analisis data yang digunakan adalah uji perbedaan dua rata-rata (uji-t) dengan taraf signifikan $(\alpha)=5 \%$. Hasil pengujian hipotesis menunjukkan bahwa: (1) ada perbedaan yang signifikan hasil belajar mahasiswa biologi yang proses pembelajarannya menggunakan pendekatan deduktif dengan induktif (2) ada perbedaan yang signifikan kemampuan berpikir kritis mahasiswa biologi yang proses pembelajarannya menggunakan pendekatan deduktif dan induktif,. Penelitian menyimpulkan bahwa pendekatan deduktif lebih baik terhadap hasil belajar dan Pendekatan induktif lebih baik terhadap kemampuan berpikir kritis mahasiswa.
\end{abstract}

Kata Kunci : pendekatan induktif, pendekatan deduktif, hasil belajar dan kemampuan berpikir kritis

ABSTRACT. This study aimed at investigating the differences between result study and critical thinking ability of biology students employing deductive and inductive learning approaches based on the ecosystem concept. This study uses comparative research, particularly posttest control group design. Besides, the population of this study the entire Second Semester Students of Biology Education Department, Faculty of Educational Sciences and Teachers' Training, Siliwangi University. Moreover, the sample of this study is two classes taken randomly by utilizing cluster random sampling with a total of 67students. In addition, technique of collecting the data was conducted by the posttest to the students in order to obtain the data about students' final learning outcomes and applying rubric for the sake of identifying the students' critical thinking abilities. Likewise, T-Test (the test using to compare the differences of two scores average) with $(\alpha)=5 \%$ as the significant level was used. The result of the data analysis and hypothesis testing, the results showed that (1) There was a significant learning outcome of Biology students employing deductive and inductive learning approaches. (2) there was a significant level of biology students' creative thinking ability applying deductive and inductive learning. As a result, deductive learning approach plausibly yielded better learning outcomes and 
Bioedusiana

Volume 01, Nomor 01, September 2016

ISSN 2477-5193

Inductive learning approach obviously influenced the students' critical thinking abilities.

Key Words: Inductive learning approach, deductive learning approach, result study and critical thinking ability.

\section{PENDAHULUAN}

Sains memiliki peranan

penting dalam pengembangan ilmu pengetahuan dan teknologi saat ini.

Sains merupakan pengetahuan yang tersusun secara sistematis yang mengandung pertanyaan, pencarian, pemahaman serta penyempurnaan jawaban tentang suatu gejala dan karakteristik alam sekitar. Sains berkaitan dengan cara mencari tahu tentang alam sehingga sains bukan hanya penguasaan kumpulan pengetahuan yang berkaitan dengan fakta-fakta, konsep-konsep atau prinsip-prinsip saja tetapi juga merupan proses penemuan. Pada hakikatnya dimensi sains dikaitkan sebagai pengetahuan, proses dan produk, serta pengembangan nilai dan sikap tertentu. Pelaksanaan pembelajaran sains yang berpijak pada hakikat sains seharusnya dapat menjadi pondasi bagi perkembangan Ilmu Pengetahuan dan Teknologi (IPTEK) ke depan.

Kenyataannya peranan sains belum sepenuhnya didukung oleh proses pembelajaran sains yang semestinya. Kebanyakan yang dirasakan oleh peserta didik dan tenaga pengajar sains masih sering dianggap sebagai kendala. Selain itu kondisi diatas diperparah dengan adanya berbagai pandangan bahwa pelajaran sains termasuk biologi merupakan pelajaran rumit, kompleks, membosankan, banyak hafalan. Oleh sebab itu, diperlukan suatu upaya perubahan proses pembelajaran termasuk pada proses pendidikan calon guru sains (biologi). Proses pembelajaran yang dilaksanakan bagi calon guru biologi tidak cukup hanya memberikan bekal berupa pengetahuan saja. Hal lain yang diperlukan adalah adanya upaya secara intensif untuk menumbuh kembangkan kesadaran dalam belajar, kecakapan dalam berpikir tingkat tinggi (High Order Thinking) salah satunya adalah berpikir kritis, kemampuan dalam memecahkan masalah dan kemampuan mengaplikasikan dan merealisasikan 
dalam kehidupan sehari-hari dalam situasi masyarakat saat ini.

Permasalahan yang menjadi bahan dalam penelitian ini adalah bagaimana membangun pemahaman dan mengembangkan kemampuan berpikir kritis mahasiswa melalui pembelajaran. Pencapaian pemahaman dan keterampilan berpikir kritis dipandang sangat penting karena tidak hanya menekankan pada aspek menghafal pengetahuan saja namun, telah menjadi salah satu kompetensi dari tujuan pendidikan perguruan tinggi di banyak Negara (Siswono (2009)

Berpikir merupakan suatu aktivitas memproses informasi secara kognisi atau suatu kegiatan mental yang melibatkan kerja otak. Berpikir kritis dalam pendidikan tinggi merupakan kompetensi yang harus dicapai serta alat yang diperlukan dalam membangun pengetahuan. Kompetensi berpikir kritis dalam pencapaiammya perlu diberikan aktivitas pembelajaran yang mengarah pada kemampuan memahami konsep dan keterampilan berpikir kritis serta didasarkan pada kebermaknaan belajar yang disesuaikan dengan konteks lingkungannya.

Berdasarkan hasil observasi yang telah dilakukuan pada mahasiswa Program Studi Pendidikan Biologi semester $\mathrm{V}$ ditemukan permasalahan dalam kegiatan pembelajaran dikelas pada Konsep Ekosistem rata-rata mahasiswa kurang begitu mampu dalam mengembangkan kemampuan berpikir kritis serta penguasaan konsepnya pun belum begitu memuaskan dengan perolehan nilai pada konsep tersebut.

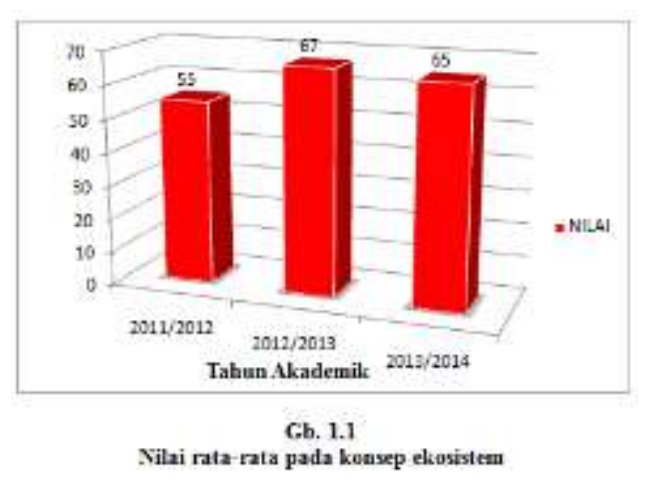

\section{Gb. 1.1}

Nilai rata-rata pada konsep ekosistem

Oleh sebab itu maka perlu adanya penggunaan pendekatan dan model pembelajaran yang tepat. Pendekatan pembelajaran yang digunakan dalam penelitian ini adalah 
pendekatan induktif dan deduktif.

Dipilihnya kedua pendekatan pembelajaran tersebut karena landasan utamanya adalah adanya kebebasan bagi peserta didik untuk dapat mengembangkan cara berpikir mereka sendiri yang memudahkan mereka dalam belajar dan memecahkan masalah belajar sesuai dengan karakteristik yang dimiliki oleh model pembelajaran Problem Based Learning (PBL) (Arief. 2007)

\section{METODE PENELITIAN}

Metode yang digunakan dalam penelitian ini adalah metode komparatif dengan pendekatan kuantitatif. Penelitian komparatif adalah penelitian yang membandingkan keberadaan satu variable atau lebih pada dua atau lebih sampel yang berbeda, atau pada waktu yang berbeda (Sugiyono, 2006).

Variabel terikat dalam penelitian ini adalah hasil belajar dan kemampuan berpikir kritis mahasiswa pada Konsep Ekosistem dan variabel bebas dalam penelitian ini adalah pendekatan pembelajaran deduktif dan induktif. Adapun populasinya adalah seluruh mahasiswa Semester II Program Studi pendidikan Biologi FKIP UNSIL dengan sampel sebanyak 2 kelas yang diambil secara cluster random sampling yaitu kelas 2A sebanyak 33 orang dan kelas 2B sebanyak 34 orang.

Desain penelitian yang digunakan adalah post test group desain. Dalam disain ini mengadakan treatment dua kali yang diperkirakan sudah mempunyai pengaruh kemudian diadakan post test. Desain penelitiannya sebagai berikut :

Rancangan :

Kelas eksperimen I : $\mathrm{R} \quad \mathrm{X}_{1} \quad \mathrm{O}_{1}$ Kelas eksperimen II : $\mathrm{R} \quad \mathrm{X}_{2} \quad \mathrm{O}_{1}$

$\mathrm{R}$ : Randomisasi

$\mathrm{X}_{1}$ : perlakuan (treatment) pertama dengan menggunakan Pendekatan pembelajaran deduktif dan observasi berpikir kritis

$\mathrm{X}_{2}$ : perlakuan (treatment) kedua dengan menggunakan pendekatan pembelajaran induktif

$\mathrm{O}_{1}$ : Pencapaian kelompok sampel setelah perlakuan untuk hasil belajar

Teknik pengumpulan data yang digunakan dalam penelitian ini yaitu teknik tes dan rubrik.Tes yang digunakan adalah test tertulis berupa soal multiple choice banyak 32 soal dengan 5 options yang dilakukan setelah proses pelaksanaan proses 
belajar mengajar. Tujuan dari pelaksanaan tes akhir adalah untuk mengetahui sejauh mana keberhasilan belajar yang telah dicapai siswa. Dan rubrik digunakan untuk mengukur tingkat kemampuan berpikir kritis mahasiswa selama proses pembelajaran berlangsung.

Instrumen yang digunakan dalam penelitian ini adalah tes untuk hasil belajar dan rubrik untuk berpikir kritis. Tes tertulis berupa soal multiple choice sebanyak 32 soal dengan 5 options untuk setiap butir soal. Aspek yang diukur merupakan ranah kognitif pada jenjang mengingat $\left(\mathrm{C}_{1}\right)$, mengerti $\left(\mathrm{C}_{2}\right)$, memakai $\left(\mathrm{C}_{3}\right)$ menganalisis $(\mathrm{C} 4)$ dan mengevaluasi (C5). Soal sebelumnya diuji coba untuk mengetahui validitas dan reliabilitas instrument, sedangkan instrumen rubrik tidak dilakukan uji instrumen.

Setelah data hasil penelitian diperoleh, dilakukan uji asusmi atau prasyarat (uji normalitas dan homogenitas) kemudian dilanjutkan uji hipotesis dengan menggunakan uji $\mathrm{t}$ independen untuk mengetahui perbedaan rata-rata hasil belajar berupa postest dan rata-rata kemampuan berpikir kritis mahasiswa biologi yang pembelajarannya menggunakan pendekatan deduktif dan induktif pada Sub Konsep Ekosistem.

\section{HASIL DAN PEMBAHASAN Hasil Penelitian}

Data hasil penelitian yang disajikan meliputi data hasil belajar berupa posttest mahasiswa berdasarkan instrumen-instrumen yang telah dilakukan uji validitas serta uji reliabilitasnya dan hasil skor berpikir kritis mahasiswa berdasarkan rubrik yang telah disediakan. Berikut dikemukakan data untuk masingmasing kelas :

\section{Kelas Deduktif}

Data hasil penelitian yang diperoleh pada kelas 2B yang menggunakan pendekatan deduktif

\section{a. Hasil Belajar Mahasiswa}

Data hasil belajar meliputi data postest untuk pembelajaran yang menggunakan pendekatan dedutif ini terdiri dari 32 soal pilihan ganda yang valid dan reliabel. Jumlah mahasiswa di kelas ini sebanyak 34 orang. Ringkasan lampiran tersebut tersaji pada tabel 1 . 
b. Kemampuan Berpikir kritis

Data kemampuan berpikir kritis mahasiswa biologiyang pembelajarannya menggunakan pendekatan deduktif diperoleh dengan menggunakan rubrik penilaian berpikir kritis yang penilainya dilakukan saat pembelajaran berlangsung yang terdiri dari 5 indikator. Berdasarkan pembelajaran dedutif meliputi :indikator dan penilaian yang tersedia dalam rubrik maka diperoleh data yang terlampir yang tersaji dalam tabel 1

\section{Tabel 1}

Skor hasil belajar dan kemampuan berpikir kritis pada kelas Deduktif

\begin{tabular}{|l|c|c|}
\hline \multirow{2}{*}{ Skor } & \multicolumn{2}{|c|}{ Jumlah Benar } \\
\cline { 2 - 3 } & Hasil Belajar & Berfikir Kritis \\
\hline Maksimum & 18 & 30 \\
\hline Minimum & 7,5 & 15 \\
\hline Rata-rata & 11,9 & 23,85 \\
\hline SD & 2,59 & 2,59 \\
\hline
\end{tabular}

\section{Kelas Induktif (2A)}

Data hasil penelitian yang diperoleh pada kelas yang menggunakan pendekatan pembelajaran Indutif meliputi :

\section{a. Hasil belajar Mahasiswa}

Data hasil belajar meliputi data postest untuk pembelajaran yang menggunakan pendekatan dedutif ini terdiri dari 32 soal pilihan ganda yang valid dan reliabel. Jumlah mahasiswa di kelas ini sebanyak 33 orang. Ringkasan lampiran tersebut tersaji pada tabel 2 .

b. Kemampuan Berpikir kritis

Data kemampuan berpikir kritis mahasiswa biologi yang pembelajarannya menggunakan pendekatan induktif diperoleh dengan menggunakan rubrik penilaian berpikir kritis yang penilainyya dilakukan saat pembelajaran berlangsung yang terdiri dari 5 indikator. Berdasarkan indikator dan penilaian yang tersedia dalam rubrik maka diperoleh data yang terlampir yang tersaji dalam tabel 2 .

\section{Tabel 2}

Skor hasil belajar dan kemampuan berpikir kritis pada kelas Induktif

\begin{tabular}{|l|c|c|}
\hline \multirow{2}{*}{\multicolumn{1}{|c|}{ Skor }} & \multicolumn{2}{c|}{ Jumlah Benar } \\
\cline { 2 - 3 } & Hasil Belajar & Berfikir Kritis \\
\hline Maksimum & 28 & 18,5 \\
\hline Minimum & 15 & 9,5 \\
\hline Rata-rata & 20,97 & 13,53 \\
\hline SD & 3,83 & 2,36 \\
\hline
\end{tabular}

\section{Pengujian Hipotesis}

Pengujian hipotesis dalam penelitian ini dengan uji beda t-test dengan menggunakan program SPSS 21. Adapun pengujian hipotesislangkah-langkah uji hipotesis dapat dijelaskan sebagai berikut:

\section{a. Hipotesis pertama}

$\mathrm{H}_{0} \quad$ : Tidak ada perbedaan hasil belajar mahasiswa biologi yang menggunaan 
pendekatan pembelajaran deduktif dengan menggunakan pendekatan pembelajaran induktif pada konsep ekosistem.

$\mathrm{H}_{\mathrm{a}}$ : Ada perbedaan hasil belajar mahasiswa biologi yang menggunaan pendekatan pembelajaran deduktif dengan menggunakan pendekatan pembelajaran induktif pada konsep ekosistem.

Berdasarkan hasil uji beda $t$ test untuk mengetahui perbedaan kedua pendekatan hasil belajar tersaji secara ringkas pada Tabel 3.

\section{Tabel 3}

Rangkuman Uji Beda $t$-test Hasil Belajar Mahasiswa Biologi

Group Statistics
\begin{tabular}{|l|c|c|c|c|}
\hline Pendekatan & $\mathbf{N}$ & Mean & $\begin{array}{c}\text { Std. } \\
\text { Deviation }\end{array}$ & $\begin{array}{c}\text { Std } \\
\text { Error } \\
\text { Mean }\end{array}$ \\
\hline Hasil belajar : & & & & \\
deduktif (2B) & 34 & 23,85 & 4,23 & 0,73 \\
Induktif(2A) & 33 & 20,97 & 3,82 & 0,67 \\
\hline
\end{tabular}

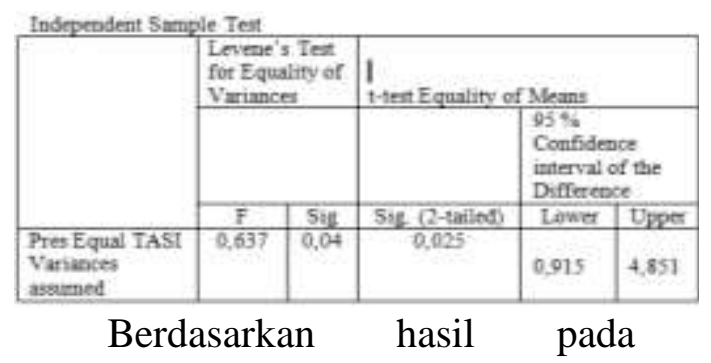

keluaran SPSS 21, tampak pada Group statistic bahwa jumlah mahasiswa untuk kedua kelas masing-masing 33 dan 34 dan ratarata hasil belajar untuk kelas 2B (pendekatan deduktif) sebesar 23,85 sedangkan kelas 2A (pendekatan induktif) sebesar 20,97. Pada keluaran Independent Samples Tes kolom t-test for Equality of Means, skore sig. (2 tailed) sebesar 0,025. Berdasarkan kriteria, bila nilai sig. (2 tailed $)<0,05$ maka Ho ditolak. Hal ini berarti terdapat perbedaan yang signifikan hasil belajar mahasiswa yang proses pembelajarannya menggunakan pendekatan deduktif dan induktif pada konsep ekosistem.

Berdasarkan hasil tersebut berarti pendekatan deduktif lebih efektif dalam perolehan hasil belajar dari pada pendekatan induktif. Keefektifan pendekatan deduktif ini dapat dilihat dari rata-rata skor sebesar 23,85 yang lebih besar dari rata-rata skor yang menggunakan pendekatan induktif sebesar 20,97.

\section{b. Hipotesis kedua}

$\mathrm{H}_{0}$ : Tidak ada perbedaan kemampuan berpikir kritis mahasiswa biologi yang menggunaan pendekatan pembelajaran deduktif dengan menggunakan pendekatan pembelajaran induktif pada konsep ekosistem.

$\mathrm{H}_{\mathrm{a}} \quad$ : Ada perbedaan kemampuan berpikir kritis mahasiswa biologi yang menggunaan 
pendekatan pembelajaran deduktif dengan menggunakan pendekatan pembelajaran induktif pada konsep ekosistem.

Berdasarkan hasil uji beda t-test untuk mengetahui perbedaan kedua pendekatan hasil belajar tersaji secara ringkas pada Tabel 4.

\section{Tabel 4}

Rangkuman Uji Beda t-test

Kemampuan Berpikir Kritis Mahasiswa Biologi

Group Statistics

\begin{tabular}{|c|c|c|c|c|}
\hline Pendekatan & $\mathrm{N}$ & Mean & $\begin{array}{l}\text { Std. } \\
\text { Deviation }\end{array}$ & $\begin{array}{l}\text { Std } \\
\text { Error } \\
\text { Mean } \\
\end{array}$ \\
\hline $\begin{array}{l}\text { Berpikir } \\
\text { Kritis } \\
\text { deduktif } \\
\text { (2B) } \\
\text { Induktif } \\
\text { (2A) }\end{array}$ & $\begin{array}{l}34 \\
33\end{array}$ & $\begin{array}{l}11,99 \\
13,53\end{array}$ & $\begin{array}{l}2,362 \\
2,532\end{array}$ & $\begin{array}{l}0,411 \\
0,434\end{array}$ \\
\hline
\end{tabular}

\begin{tabular}{|c|c|c|c|c|c|}
\hline \multicolumn{6}{|c|}{ Independent Sample Test } \\
\hline & \multicolumn{2}{|c|}{$\begin{array}{l}\text { Levene's } \\
\text { Test } \\
\text { Equality or } \\
\text { Variances }\end{array}$} & \multicolumn{3}{|c|}{ t-test Equality of Means } \\
\hline & & & & $\begin{array}{l}95 \% \\
\text { Confid } \\
\text { interva } \\
\text { Differe }\end{array}$ & $\begin{array}{l}\text { ce } \\
\text { of the } \\
\text { e }\end{array}$ \\
\hline & $\mathrm{F}$ & Sig & $\begin{array}{l}\text { Sig. } \\
\text { (2- } \\
\text { tailed }\end{array}$ & $\begin{array}{l}\text { Lowe } \\
\mathrm{r}\end{array}$ & $\begin{array}{l}\text { Uppe } \\
\mathrm{r}\end{array}$ \\
\hline $\begin{array}{l}\text { Pres } \\
\text { Equal } \\
\text { TASI } \\
\text { Variance } \\
\text { s } \\
\text { assumed }\end{array}$ & $\begin{array}{l}0,1 \\
2\end{array}$ & $\begin{array}{l}0,04 \\
9\end{array}$ & 0,018 & ,261 & 2,652 \\
\hline
\end{tabular}

keluaran SPSS 21, tampak pada Group statistic bahwa jumlah mahasiswa untuk kedua kelas masing-masing 33 dan 34 dan ratarata berpikir kritis untuk kelas 2B (pendekatan deduktif) sebesar 11,99 sedangkan kelas 2A (pendekatan induktif) sebesar 13,53. Pada keluaran Independent Samples Tes kolom t-test for Equality of Means, skore sig. (2 tailed) sebesar 0,018. Berdasarkan kriteria, bila nilai sig. (2 tailed $)<0,05$ maka Ho ditolak. Hal ini berarti terdapat perbedaan yang signifikan kemampuan berpikir kritis mahasiswa yang proses pembelajarannya menggunakan pendekatan deduktif dan induktif pada konsep ekosistem.

Berdasarkan hasil tersebut berarti pendekatan induktif lebih efektif dalam perolehan skor pkemampaun berpikir kritis dari pada pendekatan deduktif. Keefektifan pendekatan induktif ini dapat dilihat dari rata-rata skor sebesar 11,99 yang lebih besar dari rata-rata skor yang menggunakan pendekatan deduktif sebesar 13,53.

Dalam penelitian ini Hasil belajar mahasiswa yang proses pembelajarannya menggunakan pendekatan deduktif dan induktif memberikan hasil yang berbeda pada konsep ekosistem. Hal ini bisa dilihat dari hasil belajar mahasiswa yang 
proses

pembelajarannya

menggunakan pendekatan deduktif hasilnya lebih baik dari hasil belajar mahasiswa yang proses

pembelajarannya menggunakan pendekatan induktif hal ini dapat dilihat dari hasil rata-rata skor hasil belajar yang menggunakan pendekatan deduktif sebesar 23,85 dan yang menggunakan pendekatan induktif sebesar 20,97.

Mahasiswa yang mengikuti pembelajaran dengan menggunakan pendekatan deduktif ini mendapatkan peluang untuk mencari solusi yang lebih cepat sebab solusi umum dari permasalahn lebih mudah untuk ditemukan dibandingkan solusi yang lebih detail. Kondisi ini lebih menguntungkan mahasiswa sebab mengarahkan mahasiswa untuk mampu menggali solusi aktual dan kontekstual. Hal ini sesuai dengan yang diungkapkan Santyasa (2004) bahwa pembelajaran yang lebih mengutamakan pemecahan masalah yang bersifat umum, mengembangkan konsep, konstruksi solusi lebih baik dari pada menghafal prosedur dan menggunakannya untuk memperoleh satu jawaban benar.
Selanjutnya penemuan konsep umum yang ditemukan oleh mahasiswa biasanya lebih mampu diserap oleh mahasiswa karena urutan materi yang sistematis mulai dari umum ke khusus akan lebih mudah dipahami namun daya ingat mahasiswa akan jauh lebih pendek (sort term memory) sehingga jika mahasiswa tidak berlatih untuk terus mengingat materi yang diterimanya ini maka materi mudah lupa.

Selanjutnya, Dari hasil perhitungan diperoleh rata-rata kemampuan berpikir kritis mahasiswa yang diberi pendekatan induktif lebih tinggi daripada rata-rata kemampuan berpikir kritis yang diberi pendekatan deduktif. Sehingga dapat diinterpretasikan bahwa terdapat pengaruh pendekatan induktif terhadap kemampuan berpikir kritis. Pengaruh ini juga dapat dilihat dari perbedaan kemampuan berpikir kritis mahasiswa pada kelas yang menggunakan pendekatan induktif memperoleh skor tertinggi sebesar 18,5 dan skor terendah sebesar 9,5, sedangkan pada kelas yang menggunakan pendekatan deduktif 
nilai tertinggi sebesar 18 dan nilai terendah sebesar 7,5. Ini dapat dikatakan bahwa pendekatan induktif merupakan pendekatan yang efektif untuk meningkatkan kemampuan berpikir kritis mahasisiwa.

Dalam penelitian ini, lebih tingginya rata-rata kemampuan berpikir kritis mahasiswa pada konsep ekosistem yang diberi pendekatan induktif diperkuat dengan hasil pengujian hipotesis. Selain itu, ditunjang dengan kelebihankelebihan yang dimiliki oleh pendekatan induktif bahwa pendekatan ini memberikan kesempatan pada mahasiswa untuk mampu menguasai materi secara menyeluruh hal ini tentu saja dapat meningkatkan penalaran mahasiswa untuk berpikir kritis, sebab penemuan konsep yang detail akan merangsang proses berpikir sehingga hal ini dapat berpengaruh terhadap kemampuan berpikir kritisnya. Selain itu pengetahuan yang telah diperoleh dari proses pembelajaran ini dapat bertahan lama atau lama dapat diingat (long term memory) sebab penemuan konsepnya didasarkan pada urutan berpikir mendalam dan sistematis.

\section{PENUTUP \\ Simpulan}

Berdasarkan penelitian, pengolahan data, dan pengujian hipotesis, maka penulis berkesimpulan bahwa:

1. Terdapat perbedaan hasil belajar mahasiswa biologi yang menggunaan pendekatan pembelajaran deduktif dengan menggunakan pendekatan pembelajaran induktif pada konsep ekosistem. Dan Hasil belajar mahasiswa yang prose pembelajaranya menggunakan pendekatan deduktif lebih baik dari hasil belajar mahasiswa yang proses pembelajarannya menggunakan pendekatan induktif pada konsep ekosistem.

2. Terdapat perbedaan kemampuan berpikir kritis mahasiswa biologi yang menggunaan pendekatan pembelajaran deduktif dengan menggunakan pendekatan pembelajaran induktif pada konsep ekosistem. Dan kemampuan berpikir kritis mahasiswa yang prose pembelajaranya menggunakan pendekatan induktif lebih baik dari hasil belajar 
mahasiswa yang proses pembelajarannya menggunakan pendekatan deduktif pada konsep ekosistem.

\section{Saran}

Berdasarkan hasil penelitian yang telah dilakukan, makapenulis menyarankan:

1. Pendekatan deduktif bisa menjadi salah satu rujukan pendekatan yang bisa digunakan oleh dosen/guru untuk meningkatkan hasil belajar dan Pendekatan induktif dapat digunakan sebagai salah satu pendekatan yang mampu meningkatkan kemampuan berpikir kritis.

2. Terdapat hubungan antara pendekatan pembelajaran dengan motivasi belajar terhadap hasil belajar dan kemampuan berpikir kkritis, sehingga dalam penentuan pendekatan pembelajaran yang digunakan dosen disarankan mempertimbangakan faktor intern mahasiswa yang dapat berpengaruh terhadap keberhasilan pembelajaran.

3. Penggunaan pendekatan deduktif dan induktif ini bisa digunakan pada konsep dan matakuliah yang lain, namun keberhasilannya sangat tergantung dari peranan dosen.

\section{DAFTAR PUSTAKA}

Achmad, Arief. 2007. Memahami berpikir kritis. [online]. Tersedia : http://reaschengines.com/10 07arief3.html. [7 agustus 2014]

Anderso. Lorin W.; Krathwohl, David R ; Arisanian, Peter W.; Cruikshank; Kathleen A.; Mayer, Richard E.; Paul R.; Raths, James; dan Wittrock, Merlin C. (ed) (2001). A Taxonomy for Learning Teaching and Assessing $A$ revision of Bloom's Taxonomy of Educational Objectivities. Abridged Edition. New York : Longman Inc.

Ficher, Alec. 2009. Berpikir Kritis Sebuah Pengantar. Jakarta : Erlangga.

Joyce Bruce. 2009. Models of Teaching - Model-model Pengajaran. Yogyakarta: Pustaka pelajar.

Kartika, M.D. Santyasa, W. Warpala. W.2014. Pengaruh Model Pembelajaran Berbasis Massalah Terhadap Pemahaman Konsep Fisika dan Keterampilan Berfikir Kritis Fisika dan Keterampilan Berfikir Kritis Siswa. Dalam e-Journal (Vol 4). : Program 
Bioedusiana

Volume 01, Nomor 01, September 2016

ISSN 2477-5193

Pascasarjana Universitas

Pendidikan Ganesa Program

Studi

Teknologi

Pembelajaran.

Siswono, T. Y. E. 2009. Kontruksi

Teoritik tentang Tingkat

Berpikir kritis Siswa.

[Online]. Tersedi:http://

tatagyes.files.wordpress.co

$\underline{\text { m }}$ [7 agustus 2014]

Sugiyono. 2012. Metode Penelitian

Kuantitatif, kulaitatif dan

$\boldsymbol{R} \& \boldsymbol{D}$, Bandung : Alpfabeta

Syaiful Sagala. 2005 . Konsep dan

Makna Pembelajaran

Bandung: Penerbit Alfabeta 